\title{
Arsenic and polymetallic contaminants in groundwater of the arid regions of South Africa
}

\author{
T.A. Abiye \\ School of Geosciences, University of the Witwatersrand, Johannesburg, South Africa
}

\begin{abstract}
In South Africa, the majority of rural water supply comes from groundwater hosted within the weathered and fractured crystalline rocks. The main minerals that are responsible for arsenic release into groundwater in South Africa are arsenopyrite $(\mathrm{FeAsS})$, lollingite $\left(\mathrm{FeAs}_{2}\right)$ and scorodite $\left(\mathrm{FeAsO}_{4} \cdot 2 \mathrm{H}_{2} \mathrm{O}\right)$, where scorodite is an alteration product of arsenopyrite due to prolonged water-rock interaction process. Owing to the release of arsenic from highly mineralized rocks, its concentration in the groundwater reaches up to $253 \mu \mathrm{g} \mathrm{L}^{-1}$ (south western part of the country), $6150 \mu \mathrm{g} \mathrm{L}^{-1}$ (west of Johannesburg), about $500 \mu \mathrm{g} \mathrm{L}^{-1}$ in the Karoo aquifers. Acid mine drainage is also found to be important source of arsenic and other toxic metals in the environment.
\end{abstract}

\section{INTRODUCTION}

In regions that are characterized by climatic aridity and minimal rainfall, groundwater from weathered and fractured crystalline rock aquifers is a primary source of water supply for various community activities. The development of groundwater resources from these aquifers has been regarded as a very important deriver for economic growth of the country owing to its availability at shallow depth $(\approx 40 \mathrm{~m})$ and scarcity of surface water sources often characterized by poor water quality due to arsenic (As) and polymetallic contaminants. In several parts of the world, especially in south-east Asia, high As concentration is prevalent in groundwater from the sedimentary aquifers with enriched organic matter (Ahmed et al., 2004; Bhattacharya et al., 2002a,b, 2004; Mukherjee et al., 2011; Nriagu et al., 2007) related to organic rich sediments. The geology of aquifers that host As in South Africa have undergone large-scale mineralization, where As occurs in sulphide ores such as auriferous, stanniferous and antimonial deposits (Hammerbeck, 1998) that is being released into groundwater through leaching process. Arsenic, $\mathrm{U}$ and Se are more mobile under a wider range of naturally occurring groundwater conditions; hence they pose a potentially more widespread problem than other trace constituents (Sami \& Druzynski, 2003). Extensive mineralization of rocks is also responsible for the release of toxic metals into the groundwater.

\section{MATERIALS AND METHODS}

Extensive literature assessment was conducted in order to gather relevant information on the arsenic and toxic metal concentration in the groundwater system of South Africa. In order to get a first-hand information, twenty groundwater samples from granitic aquifers were collected and analyzed for 24 metals, including arsenic. The water samples were diluted in $50 \mathrm{~mL}$ polypropylene volumetric flasks with ultra-pure water and acidified with $2 \% \mathrm{HNO}_{3}$ and analyzed by IC-PMS.

\section{RESULTS AND DISCUSSION}

The geology of the main aquifers in South Africa is represented by weathered and fractured basement rocks, Bushveld igneous complex (basic and felsic intrusive rocks), dykes (pegmatite, syenite and dolerite), the Witwatersrand and Transvaal Supergroup meta-sedimentary rocks (quartzite, sandstone, shale, dolomite), the Karoo and Kalahari sedimentary rocks, meta-volcanic rocks (basalts, andesites and rhyolites) and unconsolidated costal sediments. The main minerals that are responsible for arsenic release into groundwater in South Africa are dominated by arsenopyrite (FeAsS) that has a widespread occurrence in the country, lollingite $\left(\mathrm{FeAs}_{2}\right)$ and scorodite $\left(\mathrm{FeAsO}_{4} \cdot 2 \mathrm{H}_{2} \mathrm{O}\right)$. Scordite is a main mineral phase in the withering zone. Arsenopyrite and other sulphide minerals are known to be susceptible to oxidation in near surface environments (Herath et al., 2016), where most boreholes tap water for community supply.

Owing to the release of arsenic from highly mineralized rocks into groundwater, its concentration in the groundwater reaches up to $253 \mu \mathrm{g} \mathrm{L}^{-1}$ (south western part of the country), $7000 \mu \mathrm{g} \mathrm{L}^{-1}$, west of Johannesburg (Sami \& Druzynski, 2003), about $550 \mu \mathrm{g} \mathrm{L}^{-1}$ in the Karoo aquifers, within the boreholes having variable depth. In general the arsenic content in the groundwater falls above the WHO drinking water limit $\left(10 \mu \mathrm{g} \mathrm{L}^{-1}\right)$. 
The abandoned gold tailings dams around the city of Johannesburg contain very high metal concentration that release metals into surface and ground water resources. For example, in the tailings dams the content of some metals such as $\mathrm{Cr}$ ranges from 170 to $310 \mathrm{mg} \mathrm{L}^{-1}, \mathrm{Co}=10-240 \mathrm{mg} \mathrm{L}^{-1}, \mathrm{Cu}=15-254 \mathrm{mg}$ $\mathrm{L}^{-1}$ and lead 6-34 $\mathrm{mg} \mathrm{L}^{-1}$. High uranium rich mine water with acidic $\mathrm{pH}$ decants continuously from abandoned mines into streams (Winde, 2006; Hobbs, 2011; Abiye, 2014; Abiye, et al., 2018). The high concentration of polymetallic contaminants in the groundwater was regulated by oxidation, leaching and precipitation processes besides water-rock interaction. The metal concentration in groundwater is in the order of $\mathrm{Fe}>\mathrm{Sr}>\mathrm{Zn}>\mathrm{B}>\mathrm{Mn}>\mathrm{Ni}>\mathrm{Ni}>\mathrm{Li}>\mathrm{Cr}>\mathrm{As}>\mathrm{U}$ that falls within the range of $14 \mu \mathrm{g} \mathrm{L}^{-1}$ for $\mathrm{U}$ and $3128 \mu \mathrm{g}$ $\mathrm{L}^{-1}$ for $\mathrm{Fe}$ in the Namaqualand groundwater (Abiye \& Leshomo, 2013). Fe is also the main component in the gold and coal mining regions as a result of acid mine drainage that reaches $890 \mathrm{mg} \mathrm{L}^{-1}$ (Abiye et al., 2011). In addition to the leaching of arsenic from sulphide minerals facilitated by oxidation process, oxidation of iron is also believed to contribute for the concentration of arsenic in the groundwater. The lack of aquifer flushing due to low groundwater recharge condition facilitates concentration of metals in the shallow aquifers besides severe evaporation process in the region. This zone is readily accessible by groundwater users for various economic activities.

\section{CONCLUSIONS AND RECOMMENDATIONS}

South Africa is endowed with a variety of economic minerals both metals and non-metals, which also host minerals responsible for arsenic and other toxic metals release into aquifers. Complex geochemical processes that involve oxidation and precipitation at acidic $\mathrm{pH}$ conditions are among few that mobilizes metals from host rocks into groundwater. It was also noted that acid mine drainage in the gold and coal mining areas is the primary media for arsenic and other toxic metal mobilization from sulphides and eventually contaminates water supply systems.

Due to the health related risk associated with arsenic, it is essential to take precautionary measure on boreholes with high content.

\section{ACKNOWLEDGMENT}

I would like to thank Prof. Prosun Bhattacharya for his encouragement that helped me to develop this abstract for As2018 conference.

\section{REFERENCES}

Abiye, T.A., Mengistu, H. \& Demlie, M.B. 2011. Groundwater resource in the crystalline rocks of the Johannesburg area, South Africa. J. Water Resour. Protection 3(4): 199-212.

Abiye, T.A. \& Leshomo J. 2013. Metal enrichment in the groundwater of the arid environment in South Africa. Environ. Earth Sci. 72: 4587-4598.

Abiye, T.A. 2014. Mine water footprint in the Johannesburg area: a review based on existing and measured data. South Afr. J. Geol. 117(1): 87-96.

Abiye, T.A, Mkansi, S., Masindi, K. \& Leshomo, J. 2018. Effectiveness of wetlands in retaining metals from mine water, South Africa. J. Water Environ. (in press).

Ahmed, K.M. Bhattacharya, P., Hasan, M.A., Akhter, S.H., Alam, S.M.M., Bhuyian, M.A.H., Imam, M.B., Khan, A.A. \& Sracek, O. 2004. Arsenic contamination in groundwater of alluvial aquifers in Bangladesh: An overview. Appl. Geochem. 19(2):181-200.

Bhattacharya, P., Frisbie, S.H., Smith, E., Naidu, R., Jacks, G. \& Sarkar, B. 2002a. Arsenic in the Environment: A Global Perspective. In: B.Sarkar (Ed.) Handbook of Heavy Metals in the Environment, Marcell Dekker Inc., New York, pp. 147-215.

Bhattacharya, P., Jacks, G., Ahmed, K.M., Khan, A.A. \& Routh, J. 2002b. Arsenic in groundwater of the Bengal Delta Plain aquifers in Bangladesh. Bull. Env. Contam. Toxicol. 69(4): 538-545.

Bhattacharya, P., Welch, A.H., Ahmed, K.M., Jacks, G. \& Naidu, R. 2004. Arsenic in groundwater of sedimentary aquifers. Appl. Geochem. 19(2):163-167.

Hammerbeck, E.C.I. 1998. Arsenic. In: The Mineral Resources of South Africa: Handbook, Council for Geoscience, 16, p. 40-45.

Herath, I., Bundschuh, J., Vithanage, M. \& Bhattacharya, P. 2016. Geochemical processes for mobilization of arsenic in groundwater. In: P. Bhattacharya, M. Vahter, J. Jarsjö, J. Kumpiene, A. Ahmad, C. Sparrenbom, G. Jacks, M.E. Donselaar, J. Bundschuh, \& R. Naidu (eds.) Arsenic Research and Global Sustainability As 2016". Interdisciplinary Book Series: "Arsenic in the Environment-Proceedings". Series Editors: J. Bundschuh \& P. Bhattacharya, CRC Press/Taylor and Francis (ISBN 978-1-138-02941-5), pp. 23-24.

Hobbs, P.J (Ed.) 2011. Situation assessment of the surface water and groundwater resource environments in the Cradle of Humankind World Heritage Site. Report prepared for the Management Authority. Department of Economic Development. Gauteng Province. South Africa. P424.

Mukherjee, A., Bhattacharya, P. \& Fryar, A. E. 2011. Arsenic and other toxic elements in surface and groundwater systems. Appl. Geochem. 26(4): 415-420.

Nriagu, J.O., Bhattacharya, P., Mukherjee, A.B., Bundschuh, J., Zevenhoven, R. \& Loeppert, R.H. 2007. Arsenic in soil and groundwater: an overview. In: Bhattacharya, P., Mukherjee, A.B., Bundschuh, J., Zevenhoven, R. \& Loeppert, R.H. (Eds.) Arsenic in Soil and Groundwater Environment: Biogeochemical Interactions, Health Effects and Remediation, Trace Metals and other Contaminants in the Environment, Volume 9, Elsevier B.V. Amsterdam, The Netherlands, pp. 3-60.

Sami, K. \& Druzynski, A.L. 2003. Predicted Spatial Distribution of Naturally Occurring Arsenic, Selenium and Uranium in Groundwater in South Africa-Reconnaissance Survey- WRC Report No. 1236/1/03.

Winde, F. 2006. Challenges for sustainable water use in dolomitic mining regions of South Africa- a case study of Uranium pollution: part 1 Sources and pathways. $J$. Phys. Geogr. 27 (4): 333-347. 